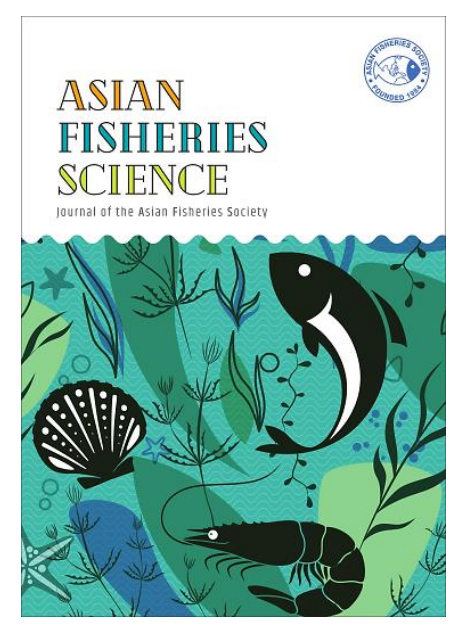

\title{
Potential Transfer of Antimicrobial Resistance and Zoonotic Bacteria Through Global Ornamental Fish Trade
}

\author{
OLGA HAENEN ${ }^{1, *}$, KEES VELDMAN ${ }^{1}$, DANIELA CECCARELLI', NEDZIB TAFRO ${ }^{2}$, TINA ZUIDEMA ${ }^{3}$, \\ DIK MEVIUS ${ }^{1}$ \\ 'Wageningen Bioveterinary Research, WBVR, P.O. Box 65, 8200 AB Lelystad, The Netherlands \\ ${ }^{2}$ The Netherlands Food and Consumer Product Safety Authority, NVWA, P.O. Box 43006, 3540 AA Utrecht, The Netherlands \\ ${ }^{3}$ Wageningen Food Safety Research, WFSR, P.O. Box 230, 6700 AE Wageningen, The Netherlands
}

(c)Asian Fisheries Society

ISSN: 0116-6514

E-ISSN: 2073-3720

https://doi.org/10.33997/j.afs.2020.33.S1.008

\section{Abstract}

There is an impressive global trade in live tropical freshwater ornamental fish. These consignments may contain potentially harmful bacteria and contaminants of therapeutics, a potential public health risk when professionals have direct contact with fish and transport water. In 2014-2015 we sampled and tested fifty consignments from 13 countries outside Europe at arrival in the Netherlands. Potential zoonotic bacteria were detected in 11 of 50 ornamental fish consignments. Aeromonas spp. $(n=59)$ isolated from fish showed resistance to oxytetracycline $(85 \%$ of strains), flumequine (53\%), trimethoprim-sulphamethoxazole (30\%), neomycin (34\%), florfenicol (9\%), and to nitrofurantoin (17\%). Isolates from fish consignments from Singapore and Congo showed multi-resistance against various antibiotics. In total 11 Escherichia coli isolates suspected of ESBL (extended-spectrum beta-lactamase)production were found in 2 of 50 freshwater ornamental fish and 9 of 50 transport water samples, from Singapore (4x), Indonesia (2x), Congo (2x), Thailand (1x), and Hong Kong Special Administrative Region of the People's Republic of China (HKSAR) (1×). OXA-48-like carbapenemase gene variants of limited public health risk were frequently found in Shewanella spp. Forty-nine of fifty water samples contained residues of one or more antibiotics, mostly tetracyclines and fluoroquinolones, but also chloramphenicol and nitrofurans, and of malachite green. Our findings are of concern since the current EU border inspections for import control do not consider these human health risks. It is therefore recommended to regularly screen consignments from more countries for the presence of antimicrobial resistant bacteria, residues of antibiotics, and potential zoonotic bacteria.

Keywords: AMR, aquaculture, diseases

\section{Introduction}

Over one billion live ornamental fish are transported globally each year, and these numbers are increasing over time (OFI, 2011). The Netherlands is a relatively important transfer and importing country of ornamental fish. Yearly, around 3000 consignments of live ornamental fish are imported into the Netherlands from approximately 40 third countries, i.e. from outside the European Union (EU). Fifty per cent of these consignments originate from South East Asia, and $80 \%$ of these are freshwater cultured fish. In $10 \%$ of all Dutch households, 11 billion ornamental fish are kept in aquaria (Dibevo, 2015).

In the international trade of live ornamental fish, antibiotics are frequently added to the transport water as a prophylactic measure to prevent the occurrence of disease during transport, in most cases tetracycline (for instance at 5-20 ppm), and less frequently nifurpirinol (Furanace ${ }^{\oplus}$ ) (for instance at 0.05-0.2 ppm) (Cole et al., 1999). This may pose a risk for humans: Groups at risk are individuals in direct skin contact with live fish, residues, and transport water containing bacteria. It includes professionals in all segments of the ornamental fish business (aquaculture and fisheries) and inspections, and to a lesser extent, persons keeping an aquarium at home.

The risk for humans may be direct, as the antibiotic may enter the body of humans via skin or ingestion when fish trade professionals do not wear protective 
clothing. The bacteria of humans may become multiresistant when exposed to these antibiotics. Moreover, the fish trade professionals may be directly exposed to bacteria which are already multiresistant against antibiotics, and this imposes a risk for transfer of resistance to other bacteria, which, in case of causing disease in humans cannot be treated anymore with the antibiotic (WHO, 2020).

Another risk for humans is the fact, that tropical freshwater fish may be carriers or be clinically infected by potential zoonotic bacteria, which may be harmful to humans via direct contact (Lehane and Rawlin, 2000; Haenen et al., 2013). The risks of contracting fish-borne contact zoonoses may be associated with the country of origin, the transfer port, if transport water is refreshed, and the target countries where live tropical fish are unpacked to enter the chain of ornamental fish trade as pets. Current EU legislation does not imply checking for parameters related to these potential human health risks at the EU border inspections posts.

Antimicrobial Resistance (AMR) is a recognised worldwide risk for human health that can spread from animals to humans by direct contact or via the food chain and environment (WHO, 2014). As a consequence of a One Health approach (McEwen and Collignon, 2018), AMR monitoring in animals should include not only food-producing animals, but also pet animals and other animals like ornamental fish. Carbapenems are broad-spectrum beta-lactam antimicrobials, which are used as last-resort options for treatment of community-acquired and healthcare-associated infections caused by multidrug-resistant (MDR) Gramnegative bacteria (Sheu et al., 2019). Since carbapenem resistance results in resistance to nearly all beta-lactam antibiotics, it narrows the therapeutic options dramatically.

Carbapenemases are extended-spectrum betalactamases (ESBLs) that hydrolyse carbapenems, lastline therapeutics to treat multidrug-resistant Gramnegative infections (Queenan and Bush, 2007). Carbapenemase-producing microorganisms are increasingly reported in livestock and fish products (Fischer et al., 2013; Stolle et al., 2013; Köck et al., 2018; Nadimpalli et al., 2019) and the environment (Woodford et al., 2014; Tacão et al., 2015). NonEuropean countries are increasingly reported in recent years as sources of multidrug-resistant bacteria and associated antimicrobial resistance genes (Gerzova et al., 2014; Verner-Jeffreys et al, 2009, WHO, 2019).

To test for parameters related to the public health risks associated with the import of live, freshwater tropical ornamental fish and their transport water from third countries, a study was conducted in the Netherlands by Wageningen Bioveterinary Research (WBVR), in close cooperation with The Netherlands Food and Consumer Product Safety Authority (NVWA) and the Wageningen Food Safety Research (WFSR).
The project was entitled "Investigation into ExtendedSpectrum Beta-Lactamase (ESBL)-, Carbapenemase Producing (CP)- bacteria and potential zoonotic bacteria in ornamental fish imported into the Netherlands, and residues of antibiotics and antiparasitics in the transport water". In this study, the NVWA selected and sampled consignments of live, freshwater tropical ornamental fish imported into the Netherlands from November 2014 to February 2015 from so-called third countries (outside the EU). The purpose was to investigate the presence of potentially zoonotic and ESBL-producing Escherichia coli and carbapenemase genes in imported freshwater tropical ornamental fish and transport water, and residues of antibiotics and leuco malachite green in the transport water, in consignments imported from outside the EU.

\section{Materials and Methods}

\section{Consignments and sampling}

The NVWA selected 50 consignments of various imported tropical freshwater ornamental fish species from countries outside Europe, mainly from Asia and South America, subsampled (2 live fish randomly per consignment, in their original transport water and bag), and sent the subsamples directly after arrival at Schiphol Airport, Amsterdam, to WBVR for analysis. At WBVR, the original transport water and the two fish per batch were sampled. All fish and water were analysed directly as given below, but part of the transport water was frozen at $-20^{\circ} \mathrm{C}$ upon analysis by WFSR.

\section{Bacteriology}

The Fish Disease Laboratory of WBVR tested both ornamental fish per consignment directly for the presence of potential zoonotic bacteria, especially Edwardsiella tarda, Streptococcus iniae, Streptoccus agalactiae, Vibrio vulnificus, Mycobacterium marinum, and other mycobacteria, and multidrug-resistant Aeromonas and Vibrio spp. In short, fish were euthanised with an overdose of 2-phenoxyethanol, and necropsied. Specimens for bacteriology were taken from the skin and internal organs of each fish. Skin specimens were inoculated onto sheep blood and thiosulfate-citrate-bile salts-sucrose (TCBS) agars. The liver was inoculated onto sheep blood agar, after which the plates were incubated at $22{ }^{\circ} \mathrm{C}$ for three days. From the isolated multi-bacterial cultures, colonies were purely cultured onto sheep blood agar for three days at $22{ }^{\circ} \mathrm{C}$ and identified by matrixassisted laser desorption/ionisation time-of-flight mass spectrometry (MALDI-TOF)(Singhal et al., 2015).

In parallel necropsy, a fresh smear of the liver of each fish was made, air dried, fixated, and Ziehl Neelsen (ZN) stained and read for the presence of mycobacteria (Sheehan et al., 2015). The livers were stored at $-80^{\circ} \mathrm{C}$ and, if $\mathrm{ZN}$ were positive, were used for mycobacteria identification by an in-house 
combination real-time PCR for three mycobacteria, Mycobacterium haemophilum, M Mycobacterium ulcerans and M. marinum (Inoue et al., 2011). The species was further identified by a second specific TaqMan real-time PCR developed in-house by WBVR (R. Ruuls, 2019, pers. comm.).

\section{Antimicrobial resistance testing}

After preliminary visual identification from isolated multi-bacterial cultures, colonies suspected of being Aeromonas and Vibrio spp. were purely cultured and identified with MALDI-TOF (Biotyper, Bruker). These bacterial isolates were stored in Buffered Peptone Water with $30 \%$ glycerol at $-80{ }^{\circ} \mathrm{C}$ upon collective antibiogram testing. Susceptibility was tested for tetracycline, flumequine, trimethoprim + sulfamethoxazole, neomycin, florfenicol, and nitrofurantoin using the disk diffusion method according to Clinical and Laboratory Standards Institute (CLSI) guidelines (document VETO3-A, CLSI, 2006). Shewanella spp. strains were sent to the AMR laboratory for further analysis.

During necropsy, the gut of each fish was directly inoculated on MacConkey-agar to isolate indicator $E$. coli, and the plates were transferred to the antimicrobial resistance (AMR) laboratory of WBVR for inoculation at $37^{\circ} \mathrm{C}$. Also, a piece of the gut was placed into a tryptone soy broth (TSB) as a nonselective enrichment step to culture possible ESBLproducing E. coli at $37^{\circ} \mathrm{C}$. Antimicrobial susceptibility testing of commensal indicator E. coli and ESBLsuspected E. coli was performed with broth microdilution according to ISO standards (ISO document 20776-1) using pre-defined panels of dehydrated antimicrobials (Sensititre plates EUVSEC and EUVSEC2, Thermo Fischer) according to EFSA guidelines (EFSA, 2012).

The AMR laboratory of WBVR tested the gut of the ornamental fish and the original transport water for the presence of ESBL-producing $E$. coli by inoculating $10 \mu \mathrm{L}$ of the incubated TSB on MacConkey agar plates with $1 \mathrm{mg} . \mathrm{L}^{-1}$ cefotaxime. In addition, purified DNA from the TSB enrichment was tested for the presence of carbapenemase genes using a commercial RT-PCR (CarbaCheck MDR RT, CheckPoints, Wageningen, NL). From a random set of 12 samples tested positive for blaOXA-48 with PCRadditional selective culturing was performed by inoculating selective media with $10 \mu \mathrm{l}$ TSB for isolation of carbapenemase-producing Enterobacteriaceae (Chrom ID Carba en ChromID OXA plates) and Shewanella (heart infusion agar plates with $5 \%$ sheep blood (HIS) and 0.125 mg. L $^{-1}$ ertapenem) as described earlier by Ceccarelli et al. (2017). Suspected Shewanella isolates were pure cultured and identified with MALDI-TOF (Singhal et al., 2015). Susceptibility of Shewanella was determined with broth microdilution using the same antibiotic panels as used for testing $E$. coli. The presence of blaxa genes was confirmed by PCR and Sanger sequencing. Conjugations and transformation experiments were performed to test for possible transfer of the bla oxa genes. As all transmission experiments showed negative results, the suspected chromosomal location of the genes was confirmed by performing pulse-field gel electrophoresis (PFGE) of I-CEU1 digested total DNA followed by Southern blot hybridisation. To exclude potential spread of the bla oxA genes, isolates were screened for the presence of transposon IS1999 with PCR. This transposon is strongly linked to the presence of bla XXA-48 $_{\text {genes on }}$ IncL/M plasmids in humans.

\section{Residue testing}

WFSR analysed the original transport water samples for residues of antibiotics. A microbial screening method based on the Nouws antibiotic test (Pikkemaat et al., 2008) was used to determine whether residues of tetracyclines, sulfonamides, macrolides, fluoroquinolones, $\quad \beta$-lactams, aminoglycosides, florfenicol, and colistin were present. For the determination of chloramphenicol, an immunochemical screening method (EIA) was used. The principle of this method is based on an antigen-antibody reaction followed by a photometric determination of chloramphenicol. For the confirmation of suspect samples for antibiotics and chloramphenicol (results from the screening tests) and for the determination of nitrofurans and leuco malachite green, instrumental methods based on liquid chromatography-mass spectrometry/massspectometry (LC-MS/MS) were used (Verdon et al., 2007; Hurtaud-Pessel et al., 2011; Berendsen et al., 2015).

\section{Results}

\section{Consignments and sampling}

The list of consignments included in the study and countries of origin is given in Table 1. Consignments arrived in boxes at Schiphol Airport (Fig. 1), containing bags with live fish. Thirty six different fish species were sampled at WBVR, predominantly Corydoras spp. (2× a batch), Corydoras paleatus (Jenyns, 1842) (2x), Xiphophorus maculatus (Günther, 1866) blue (2x), Poecilia reticulata Peters, 1859 (guppy, 5x), and Carassius auratus (Linnaeus, 1758)(8x). Only one of 50 consignments had diseased fish (Fig. 2), two consignments had fish with light mechanical injuries, and one consignment had anorexic fish.

\section{Bacteriology}

After 2 to 3 days incubation of the inoculated agar plates at $22^{\circ} \mathrm{C}$, only one plate out of 50 consignments showed no bacterial growth. From the other 49 fish consignments, 321 pure bacterial cultures were retrieved, mostly from the skin; these were subcultured again for 3 days and identified by MALDI-TOF. This resulted in 49 unidentifiable bacterial isolates, 55 
Table 1. Imported consignments of live, freshwater tropical ornamental fish (consisting of 36 different species) from countries outside Europe. Per consignment, two live fish and their original transport water were tested.

\begin{tabular}{ll}
\hline Country of origin of the fish & Number of consignments of fish of this study \\
\hline Brazil & 2 \\
China & 1 \\
\hline Colombia & 2 \\
\hline Congo & 2 \\
Hong Kong (China) & 3 \\
Indonesia & 8 \\
\hline Israel & 6 \\
\hline Peru & 1 \\
\hline Singapore & 18 \\
\hline Sri Lanka & 3 \\
\hline Thailand & 4 \\
\hline Grand total & 50 \\
\hline
\end{tabular}

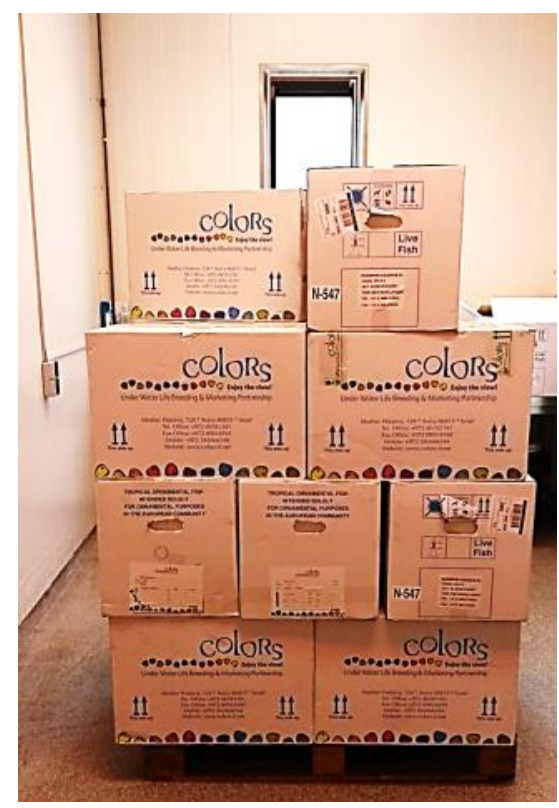

Fig. 1. Ornamental fish containers at arrival at Schiphol Airport with prescribed labelling, and filled with bags with live fish.
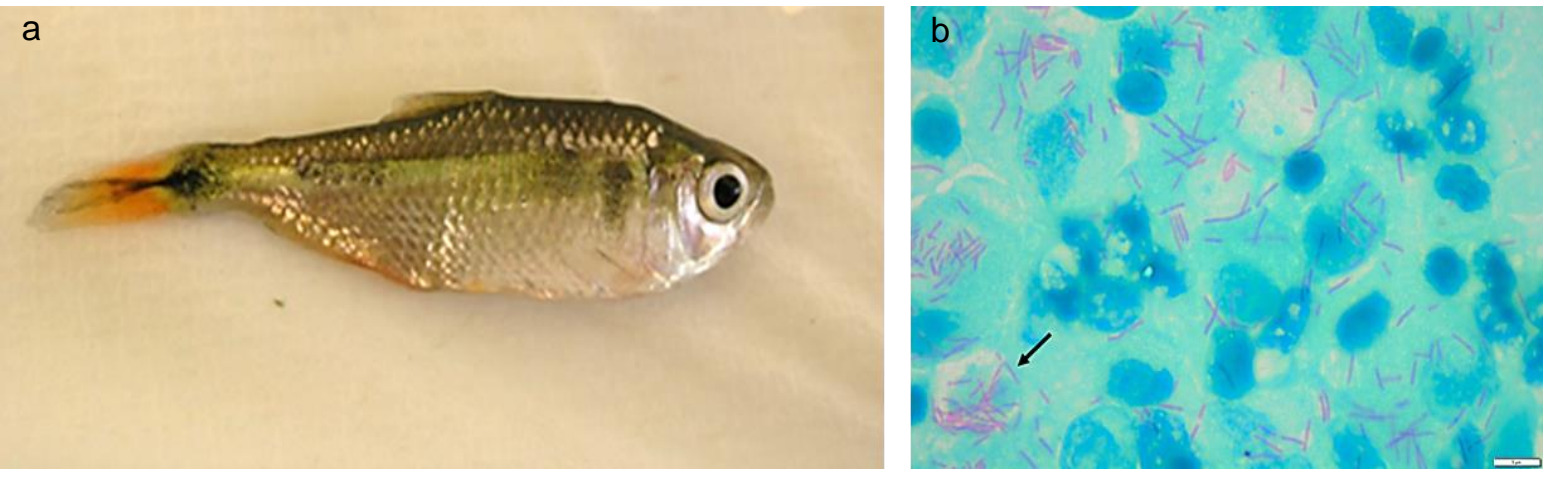

Fig. 2. Mycobacterium haemophilum was detected in one Buenos Aires tetra (Hemigrammus caudovittatus) from Indonesia: (a) The fish did not show clear clinical signs, except for a congested tail; (b) Ziehl Neelsen stain of a liver smear of the fish exhibiting many bright pink acid fast rods (indicated by the arrow). 
bacterial isolates identifiable up to genus level, and 217 bacterial isolates identifiable up to species. Of these, 59 Aeromonas spp. and three Vibrio spp. were selected for an antibiogram. Shewanella spp. were isolated $24 \times$ in total, in 12 consignments of 50 , mostly from the skin of fish, and were analysed by the AMR laboratory, as given below.

Regarding potential zoonotic bacteria, Elisabethkingia meningoseptica was found in nine fish consignments, of which five consignments were from Singapore (2 C. auratus (goldfish), 1 C. paleatus, 1 Corydoras aeneus (Gill, 1858) longfin, and 1 Hyphessobrycon bentosii Durbin, 1908, three consignments from Sri Lanka (1 Poecilia sphenops Valenciennes, 1846, 2 Poecilia reticulata (guppy)), and one batch from Brazil (Otocinclus spp.). Mycobacterium haemophilum was detected by PCR in one consignment from Indonesia (1 Hemigrammus caudovittatus (Eigenmann, 1907)) (Fig. 4). In one consignment from China (1 C. auratus) a Mycobacterium spp. was detected. By our PCRs this bacterium appeared not further identifiable to species. It was not M. marinum, M. ulcerans, nor M. haemophilum. Overall, regarding potential contact zoonotic bacteria in our monitoring, in 50 consignments of tropical freshwater ornamental fish we detected $9 \mathrm{E}$. meningoseptica positives, and 2 mycobacteria positives. No M. marinum (known to cause fish tuberculosis) was detected, and no $V$. vulnificus, E. tarda, S. iniae, nor S. agalactiae were isolated from the imported fish.

\section{Antimicrobial resistance testing}

In Aeromonas spp., $85 \%$ of the 59 isolates showed resistance against tetracycline, $53 \%$ against flumequine, $30 \%$ against trimethoprim + sulfamethoxazole, $34 \%$ against neomycin, $9 \%$ against florfenicol, and $17 \%$ against nitrofurantoin. One of the Vibrio spp. $(n=3)$ showed resistance to oxytetracycline, and only one also to neomycin. Furthermore, the 3 Vibrio spp. were sensitive to the fore-mentioned antibiotics. Aeromonas species from fish originating from Singapore and Congo showed the highest levels of resistance.

Commensal indicator E. coli were identified in 10 out of 50 consignments by non-selective isolation on MacConkey agar. In three consignments, both fish and transport water samples were positive for E. coli indicative of faecal contamination. E. coli isolates exhibited relatively high resistance percentages for ampicillin $(80 \%)$, chloramphenicol (53 \%), quinolones $(47 \%)$, sulfonamides ( $87 \%)$, trimethoprim $(93 \%)$ and tetracyclines $(100 \%)$. On top of that $53 \%$ of the isolates showed a specific quinolone resistance phenotype indicative for the presence of plasmidmediated quinolone resistance (PMOR) exhibiting resistance to ciprofloxacin, but not to nalidixic acid. The presence of these PMOR genes was not confirmed by molecular analysis.
ESBL-suspected E. coli isolates were detected in 11 of the 50 consignments $(18 \%)$, often exhibiting a multiresistant profile (resistant to 3 or more antimicrobial classes). Molecular analysis revealed the presence of different ESBL/AmpC-genes (b/a $a_{\mathrm{CMY}-2}(n=$ 4), $\operatorname{bla}_{\text {DHA-2 }}(n=1) b \operatorname{bla} a_{\text {CTX-M-1 }}(n=1)$, bla $a_{\text {CTX-M-14 }}(n=1)$ and bla $\left.a_{\text {CTX-M-15 }}(n=4)\right)$. In addition, PMOQR genes were identified in four isolates. One isolate harboured qnrB4 coinciding with qnrS1, two isolates solely qnrS1 and one isolate $a a c\left(6^{\prime}\right)-1 b$.

All samples of fish and transport water were tested negative for the carbapenemase genes b/a $a_{\mathrm{KPC}}, \mathrm{bla}_{\mathrm{NDM}}$, bla $_{\mathrm{MPP}}$ and bla $a_{\mathrm{VI}}$. However, in 41 out of 50 consignments (82 \%) variants of bla $0 \times 4-48$ were identified. Susceptibility testing of 16 Shewanella isolates from 12 consignments revealed high levels of resistance to quinolones (69\%), tetracycline (69\%), sulfonamides ( $56 \%$ ) and trimethoprim ( $56 \%$ ) and to a lesser extend to chloramphenicol (31\%). In addition, resistance to colistin was detected in two isolates (13 $\%)$ and to azithromycin in only one isolate (6\%). In a subset of seven Shewanella isolates originating from seven different consignments bla $0 \times A-48$-like genes (predominantly $\left.b / a_{0 \times A-48 b}\right)$ were confirmed to be chromosomally located.

\section{Residue testing}

Forty nine of 50 (98\%) water samples tested at WFSR contained one or more types of antibiotics, as depicted in Table 2. Most frequently found were oxytetracyclines, in concentrations from 7 to 6300 $\mu \mathrm{g} . \mathrm{L}^{-1}$. Furthermore, regarding quinolones, ciprofloxacin and enrofloxacin were found in 32 of 50 transport water samples, in concentrations between 12 to $13000 \mu \mathrm{g} \cdot \mathrm{L}^{-1}$. Additionally, oxolinic acid was detected only in 4 water samples, all from Singapore, in concentrations of 5.3 to $13 \mu \mathrm{g} \cdot \mathrm{L}^{-1}$. However, none of the 50 water samples contained detectable flumequine, nor other fluoroquinolones. Results also showed 26 of 50 water samples contained chloramphenicol, 34 nitrofuranes, and 7 the nonlicenced malachite green. There was no relation between the country of origin or fish species and the detected antibiotic.

Table 2. Number of antibiotics/(leuco) malachite green positive transport water consignments of 50 imported tropical freshwater fish consignments from countries outside Europe imported into the Netherlands with range of concentrations.

\begin{tabular}{lll}
\hline Drug & $\begin{array}{l}\text { \# of positives of } \\
50\end{array}$ & $\begin{array}{l}\text { Range } \\
\left(\mu \mathrm{g} . \mathrm{L}^{-1}\right)\end{array}$ \\
\hline (Oxy)tetracycline $^{-17}$ & 7 to 6300 \\
Quinolones $^{1}$ & 32 & 12 to 13000 \\
Chloramphenicol $^{\text {Nitrofurans }}$ & 26 & 0.2 to 40.0 \\
(Leuco)malachite green $^{-7}$ & 34 & 0.1 to 39 \\
\hline
\end{tabular}

${ }^{1}$ Only ciprofloxacin, enrofloxacin, and oxolinic acid were detected. 


\section{Discussion}

\section{Bacteriology of imported tropical ornamental fish and risk of zoonosis}

The potential zoonotic bacteria found have been reported to cause human disease in scarce cases, particularly in immunocompromised patients: $E$. meningoseptica has been incidentally associated with meningitis in immunocompromised patients, especially in neonatal intensive care, and seldom causes nosocomial pneumonia, endocarditis, postoperative bacteraemia, and other infections (Tuon et al., 2007). Mycobacterium haemophilum may cause skin ulcers and arthritis in immunocompromised humans and is seldom associated with lung inflammation, and, in healthy children, cervical and perihilar lymphadenitis (Lindeboom et al., 2011).

Overall, from this study, the risk of infection with zoonotic bacteria is estimated as low if standard hygiene is practised. At a minimum, this includes washing hands, arms, face, and other exposed areas of skin with soap and warm water after contact with ornamental fish or their water.

\section{Antimicrobial resistance}

The presence of $E$. coli in $20 \%$ of the consignments is indicative for faecal contamination. However, the origin of these bacteria remains unclear. It could either be caused by human contamination or could belong to the endogenous flora of the fish. Nevertheless, the high level of resistance for the antibiotics tested ranging from $47 \%$ to $100 \%$ is noteworthy. These resistance percentages are substantially higher than those reported in livestock in the Netherlands in the same period (MARAN, 2015). ESBL/AmpC-producing E. coli were identified in $22 \%$ of the consignments. The molecular typing of the responsible resistant genes revealed the presence of ESBL/AmpC genes commonly present in animals sources in Europe $\left(b / a_{\text {СТX-M-1 }}\right.$ and bla $\left.a_{\text {СMY-2 }}\right)$. Other genes found are more commonly present in humans in South-East Asia $\left(\right.$ bla $\left(a_{\mathrm{CTX}-\mathrm{M}-14}\right)$ or considered to be pandemic in humans $\left(b_{1} / a_{C T X-M-15}\right)$, but were also identified in animals. In addition, Plasmid Mediated Quinolone Resistance (PMOQR) genes, which are incidentally found in E. coli in livestock in Europe, were frequently identified. The combined presence of ESBL and PMOR genes are indicative of a high selective environment.

All samples were negative for carbapenemase families bla $a_{K P C}, b / a_{N D M}, b / a_{I M P}$ and bla $a_{V I M}$. However, a high percentage $(82 \%)$ of the consigments was tested positive for bla $a_{0 \times A}-48$-like genes due to the presence of Shewanella spp. Shewanella are commonly present in aqueous environments and frequently harbour OXA48-like genes on their chromosomes. For this reason, these genes are considered to be non-transferable (Ceccarelli et al., 2017). Consequently, Shewanella harbouring OXA-48-like genes are not considered to be a public health risk. Still, a high percentage of the Shewanella was multidrug resistant which is another indication of the selective environment.

\section{Residues}

Forty nine of 50 water samples contained residues of one or more types of antibiotics, with tetracyclines and fluoroquinolones detected most frequently. These antibiotics are registered in the EU to use for animal husbandry animals. For the tetracylines, particularly tetracycline and oxytetracycline, concentrations comparable to therapeutic use (Yanong, 2019) (>1000 $\left.\mu \mathrm{g} \cdot \mathrm{L}^{-1}\right)$ and much higher were detected. The most common fluoroquinolones detected were enrofloxacin and its metabolite ciprofloxacin, with concentrations reaching 13000 $\mu \mathrm{g} . \mathrm{L}^{-1}$. Since fluoroquinolones are very potent, these concentrations are within the therapeutic range for fish (Reimlinger et al., 1990).

Remarkably, a large number of samples contained the EU-banned antibiotics chloramphenicol $(36 \%)$ and nitrofurans (68\%) (EU, 2010), and (14\%) the nonlicensed malachite green (EU, 2004). Although the level of residues of the aquaculture-banned (EU, 2004) antiparasitic and antifungal drug leuco malachite was below the minimum required performance level (MRPL), these drugs are assigned as teratogenic and mutagenic, and therefore, any contact with humans needs to be avoided (Culp et al., 2002). Since 1983, (leuco) malachite green has been banned in food-related products by the United States Department of Agriculture (Andersen et al., 2005).

A positive correlation was found between high concentrations of tetracyclines or fluoroquinolones in certain water samples and resistance to these antibiotics in Aeromonas and Vibrio spp. isolated from fish which had been transported in those water samples. This suggests that resistant bacteria may have been selected by inappropriate use of antibiotics at ornamental fish farms and centres exporting the tropical ornamental fish. Therefore, antibiotic use should be reduced to a minimum, and if used at ornamental fish farms, export centres, and during transport (in transport water), only in a responsible and prudent way (World Health Organisation for Animal Health (OIE), 2020).

Awareness about these risks for the ornamental fish branch, fish hobbyists, veterinarians, medical practitioners, and governmental authorities is important. Hygienic measures must be in place to avoid contact with zoonotic infections. If antibiotics are needed, there should be responsible and prudent use of antibiotics, and the addition of antibiotics to transport water should be avoided, to reduce the likelihood of AMR selection. Regular screening for potential zoonotic bacteria and antimicrobial resistance of bacteria from imported ornamental fish 
is important. At import, bags with live ornamental fish and small volumes of transport water are diluted with freshwater directly after arrival at the import sites of ornamental fish. This will result in fast dilution and disposal of antibiotics via the drain. Therefore, it is recommended to screen more samples in international trade of ornamental fish, and from more countries, for the presence of antibiotic resistant bacteria, residues of antibiotics, and potential zoonotic bacteria. This will be instrumental in developing international guidelines to protect human health related to the import of live tropical ornamental fish, as these may pose a risk to human health during direct contact with fish and transport water. Lastly, good hygiene practices should be in place at transfer centres of ornamental fish to reduce the risk of zoonosis and AMR transfer. This should include good communication of the best hygiene practices via educative flyers and on-site demonstrations.

\section{Conclusion}

In summary, this study showed that almost all tropical freshwater fish transport water samples of imported consignments into Schiphol contained low to high concentrations of residues of authorised and nonauthorised antibiotics. Malachite green was also detected, a carcinogenic substance to animals and man, which is of concern. Most fish consignments did not show any signs of fish disease, although some potential zoonotic bacteria were detected such as Elisabethkingia meningoseptica and Mycobacterium spp. Immunocompromised humans may be at risk. In addition, multidrug-resistant bacteria were found in almost all consignments included in this study. This indicates a selective environment caused by the high use of antibiotics at ornamental fish farms sector from outside the EU during farming and transport.

However, when good hygiene is practised in the ornamental fish transport chain, the risk to humans is estimated as low. Fish mostly carried opportunistic Aeromonas spp., which were mainly resistant against oxytetracycline. Moreover, fish bacteria from Singapore and Congo showed relatively high levels of multi-resistance to antibiotics. Fish imports may pose public health risks especially because of direct contact with infected fish (zoonotic infections) or because of direct contact with possible AMR bacteria in the transport water. Current EU border inspections for import control do not consider these risks.

Therefore, we recommend to regularly screen consignments from various countries for the presence of antimicrobial resistant bacteria, residues of antibiotics, and potential zoonotic bacteria, and implement standard hygiene throughout the global ornamental fish transport chain.

\section{Acknowledgements}

We thank NVWA for subsidising this project and for their assistance in sampling. We thank Linda Stolker from WFSR, and Ineke Roozenburg-Hengst, Betty van Gelderen, Alieda van Essen, Michal VoorbergenLaarman, Joop Testerink, Marga Japing, Robin Ruuls, and Karel Riepema from WBVR for their technical laboratory assistance.

\section{References}

Andersen, W.C., Turnipseed, S.B. Roybal, J.E. 2005. Quantitative and confirmatory analyses of malachite green and leucomalachite green residues in fish and shrimp. Laboratory Information Bulletin, LIB 4363 (21):1-25. https://doi.org/10.1021/jf0532258

Berendsen, B.J.A., Wegh, R.S., Memelink, J., Zuidema, T., Stolker, L.A.M. 2015. The analysis of animal faeces as a tool to monitor antibiotic usage. Talanta 132:258-268. https://doi.org/10.1016 lj.talanta.2014.09.022

Ceccarelli, D., Van Essen-Zandbergen, A., Veldman, K.T., Tafro, N., Haenen, O., Mevius, D.J. 2017. Chromosome-encoded blaoxa-48-like variants in Shewanella spp. from food-producing animals, fish and the aquatic environment. Antimicrobial Agents and Chemotherapy 61:1013-1016. https://doi.org/10.1128/AAC.01013-16

Clinical and Laboratory Standards Institute (CLSI). 2006. Methods for antimicrobial disk susceptibility testing of bacteria isolated from aquatic animals; Approved guideline. CLSI document VETO3-A, 26:23. Clinical and Laboratory Standards Institute, 950 West Valley Road, Suite 2500, Wayne, Pennsylvania 19087 USA. https://clsi.org Imedia/1528/vet03a_sample.pdf (Accessed 17 November 2020).

Cole, B., Tamaru, C.S., Bailey, R., Brown, C., Ako, H. 1999. Shipping practices in the ornamental fish industry. Center for Tropical and Subtropical Aquaculture. Publication no. 131. http://www.ctsa.org /files/publications/CTSA_1316316728603111649761.pdf (Accessed 17 Nov 2020).

Culp, S.J., Beland, F.A., Heflich, R.H., Benson, R.W., Blankenship, L.R., Webb, P.J., Mellick, P.W., Trotter, R.W., Shelton, S.D., Greenlees, K.J., Manjanatha, M.G. 2002. Mutagenicity and carcinogenicity in relation to DNA adduct formation in rats fed leucomalachite green. Mutation Research 506-507:55-63. https://doi.org/10.1016/s0027$\underline{\text { 5107(02)00152-5 }}$

Dibevo. 2015. Ornamental Fish in Top-3 of private home pet animals in The Netherlands. (Original title: Siervissen in top-3 van meest gehouden huisdieren). https://dibevo.nl/pers/siervissen-in-top-3van-meest-gehouden-huisdieren (Accessed 21 October 2020).

EFSA. 2012. Technical specifications on the harmonised monitoring and reporting of antimicrobial resistance in Salmonella Campylobacter and indicator Escherichia coli and Enterococcus spp. bacteria transmitted through food. EFSA Journal 10:2742. https://doi.org/10.2903/j.efsa.2012.2742

EU. 2004. 2004/25/EC: Commission Decision of 22 December 2003 amending Decision 2002/657/EC as regards the setting of minimum required performance limits (MRPLs) for certain residues in food of animal origin (Text with EEA relevance) (notified under document number C(2003) 4961). Official Journal Legislation 006, 10/01/2004. pp. 38-39. https://eur-lex.europa.eu/legal-content/en/TXT /?uri=CELEX\%3A32004D0025 (Accessed 17 November 2020).

EU. 2010. Commission regulation EU No. 37/2010 of 22 December 2009 on pharmacologically active substances and their classification regarding maximum residue limits in foodstuffs of animal origin. Official Journal Legislation 15:1-72. https://eur-lex.europa.eu/legalcontent/EN/TXT/?uri=CELEX\%3A32010R0037 (Accessed 17 November 2020). 
Fischer, J., Rodríguez, I., Schmoger, S., Friese, A., Roesler, U., Helmuth, R., Guerra, B. 2013. Salmonella enterica subsp. enterica producing VIM-1 carbapenemase isolated from livestock farms. Journal of Antimicrobial Chemotherapy 68:478-480. https://doi.org /10.1093/jac/dks393

Gerzova, L., Videnska, P., Faldynova, M., Sedlar, K., Provaznik, I., Cizek, A., Rychlik, I. 2014. Characterization of microbiota composition and presence of selected antibiotic resistance genes in carriage water of ornamental fish. PLoS One 9:e103865. https://dx.doi.org /10.1371\%2Fjournal.pone.0103865

Haenen, O.L.M., Evans J.J., Berthe, F. 2013. Bacterial infections from aquatic species: Potential for and prevention of contact zoonoses. Revue Scientifique et Technique 32:497-507. https://doi.org $\underline{110.20506 / \text { rst.32.2.2245 }}$

Hurtaud-Pessel, D., Couedor, P., Verdon, E. 2011. Liquid chromatography-tandem mass spectrometry method for the determination of dye residues in aquaculture products: Development and validation. Journal of Chromatography $A$ 1218:1632-1645. https://doi.org/10.1016/j.chroma.2011.01.061

Inoue, M., Tang, W.Y., Wee, S.Y., Barkham, T. 2011. Audit and improve! Evaluation of a real-time probe-based PCR assay with internal control for the direct detection of Mycobacterium tuberculosis complex. European Journal of Clinical Microbiology and Infectious Diseases 30:131-135. https://doi.org/10.1007/s10096-010-1059-z

Köck, R., Daniels-Haardt, I., Becker, K., Mellmann, A., Friedrich, A.W., Mevius, D., Schwarz, S., Jurke, A. 2018. Carbapenem-resistant Enterobacteriaceae in wildlife, food-producing, and companion animals: a systematic review. Clinical Microbiology and Infection 24:1241-1250. https://doi.org/10.1016/j.cmi.2018.04.004

Lehane. L., Rawlin, G.T. 2000. Topically acquired bacterial zoonoses from fish: a review. The Medical Journal of Australia 173:256-259. https://doi.org/10.5694/j.1326-5377.2000.tb125632.x

Lindeboom, J.A., Bruijnesteijn van Coppenraet, L.E.S., van Soolingen, D., Prins, J.M., Kuijper, E.J. 2011. Clinical manifestations, diagnosis, and treatment of Mycobacterium haemophilum infections. Clinical Microbiology Reviews 24:701-717. https://doi.org/10.1128 lcmr.00020-11

MARAN. 2015. Monitoring of antimicrobial resistance and antibiotic usage in animals in the Netherlands in 2014. Part 2. de Greeff, S.C., Mouton, W. (Eds.). 72 pp. https://www.rivm.nl/bibliotheek /rapporten/2015-0113.pdf (Accessed 17 November 2020).

McEwen, S.A., Collignon, P.J. 2018. Antimicrobial resistance: a One Health perspective. Microbiology Spectrum 6:ARBA-0009-2017. https://doi.org/10.1128/microbiolspec.ARBA-0009-2017

Nadimpalli, M., Vuthy, Y., de Lauzanne, A., Fabre, L., Criscuolo, A., Gouali, M., Huynh, B.-T., Naas, T., Phe, T., Borand, L., Jacobs, J., Kerléguer, A., Piola, P. Guillemot, D., Le Hello, S., DelarocqueAstagneau, E. 2019. Meat and fish as sources of extended-spectrum $\beta$-lactamase-producing Escherichia coli, Cambodia. Emerging Infectious Diseases 25:126-131. https://dx.doi.org/10.3201 leid2501.180534.

Ornamental Fish International (OFI). 2011. Ornamental fish industry data. https://www.ofish.org/ornamental-fish-industry-data (Accessed 17 November 2020).

Pikkemaat, M.G., Oostra-van Dijk, S., Schouten, J., Rappallini, M., Van Egmond, H.J. 2008. A new microbial screening method for the detection of antimicrobial residues in slaughter animals: The Nouws antibiotic test (NAT-screening). Food Control 19:781-789. https://doi.org/10.1016/j.foodcont.2007.08.002

Queenan, A.M., Bush, K. 2007. Carbapenemases: the versatile $\beta$ Lactamases. Clinical Microbiology Reviews 20:440-458. https://doi.org/10.1128/cmr.00001-07
Reimlinger, M., Hoffmann, R., Pfeil-Putzien, C., Scheinert, P. 1990. Enrofloxacin, ein neues Therapeutikum für Zierfische (Enrofloxacin, a new drug for ornamental fish). Tierärztliche Praxis 18:653-657. https://europepmc.org/article/med/2080513 $\quad$ (Accessed 17 November 2020). (in German).

Sheehan, D., Hrapchak, B., Carson, F. 2015. Acid-fast bacteria - ZiehlNeelsen stain (Afb). http://www.biolabprotocols.com /details/755/Acid-Fast-Bacteria-Ziehl-Neelsen-Stain-Afb.html (Accessed 17 November 2020).

Sheu, C.C., Chang, Y.T., Lin. S.Y., Chen, Y.H., Hsueh, P.R. 2019. Infections caused by Carbapenem-resistant Enterobacteriaceae: An update on therapeutic options. Frontiers in Microbiology 10:80. https://doi.org/10.3389/fmicb.2019.00080

Singhal, N., Kumar, M., Kanaujia, P.K., Virdi, J.S. 2015. MALDI-TOF mass spectrometry: an emerging technology for microbial identification and diagnosis. Frontiers in Microbiology 6:791. https://doi.org/10.3389/fmicb.2015.00791

Stolle, I., Prenger-Berninghoff, E., Stamm, I., Scheufen, S., Hassdenteufel, E., Guenther, S., Bethe, A., Pfeifer, Y., Ewers, C. 2013. Emergence of OXA-48 carbapenemase-producing Escherichia coli and Klebsiella pneumoniae in dogs. Journal of Antimicrobial Chemotherapy 68:2802-2808. https://doi.org/10.1093/jac/dkt259

Tacão, M., Correia, A., Henriques, I.S. 2015. Low prevalence of carbapenem-resistant bacteria in river water: resistance is mostly related to intrinsic mechanisms. Microbial Drug Resistance 21:497506. https://doi.org/10.1089/mdr.2015.0072

Tuon, F.F., Campon, L., Duboc de Almeida, G., Gryschek, R.C. 2007. Chryseobacterium meningosepticum as a cause of cellulitis and sepsis in an immunocompetent patient. Journal of Medical Microbiology 56:1116-1117. https://doi.org/10.1099/jmm.0.47111-0

Verdon, E., Couedor, P., Sanders, P. 2007. Multi-residue monitoring for the simultaneous determination of five nitrofurans (furazolidone, furaltadone, nitrofurazone, nitrofurantoine, nifursol) in poultry muscle tissue through the detection of their five major metabolites ( $A O Z, A M O Z, S E M, A H D, D N S A H$ ) by liquid chromatography coupled to electrospray tandem mass spectrometry-in-house validation in line with Commission Decision 657/2002/EC. Analytica Chimica Acta 486:336-347. https://doi.org/10.1016/j.aca.2007.01.024

Verner-Jeffreys, D.W., Welch, T.J., Schwarz, T., Pond, M.J., Woodward, M.J., Haig, S.J., Rimmer, G.S., Roberts, E., Morrison, V., BakerAustin, C. 2009. High prevalence of multidrug-tolerant bacteria and associated antimicrobial resistance genes isolated from ornamental fish and their carriage water. PLoS One 4:e8388. https://doi.org/10.1371/journal.pone.0008388

WHO. 2014. Antimicrobial resistance - global report on surveillance. World Health Organization. 256 pp. https://apps.who.int/iris /bitstream/handle/10665/112642/9789241564748_eng.pdf (Accessed 03 November 2020).

WHO. 2020. Antimicrobial resistance. Fact sheet, World Health Organization. https://www.who.int/news-room/fact-sheets/detail lantimicrobial-resistance (Accessed 21 October 2020).

Woodford, N., Wareham, D.W., Guerra, B., Teale, C. 2014. Carbapenemase-producing Enterobacteriaceae and nonEnterobacteriaceae from animals and the environment: an emerging public health risk of our own making? Journal of Antimicrobial Chemotherapy 69:287-291. https://doi.org/10.1093/jac/dkt392

World Health Organization for Animal Health (OIE). 2020. Antimicrobial use in aquatic animals. Section 6. In: Aquatic animal health code. https://www.oie.int/index.php?id=171\&L=0\&htmfile=titre_1.6.htm (Accessed 17 November 2020).

Yanong, R. 2019. Use of antibiotics in ornamental fish aquaculture. University of Florida, IFAS Extension, Leaflet CIR 84. Original 
publication date January 2003. Revised July 2006, July 2013, and

December 2016. Reviewed December 2019. 7 pp.

https://edis.ifas.ufl.edu/pdffiles/FA/FA08400.pdf (Accessed 17

November 2020).

54 Asian Fisheries Science 33.S1(2020):46-54 